\title{
KAJIAN TEOLOGIS PENDAMPINGAN ORANG TUA TERHADAP ANAK DALAM BELAJAR DIMASA PANDEMIK CORONAVIRUSES DISEASE 2019
}

\author{
Overianus Halawa $\left.{ }^{1}\right)$, Manase Gulo ${ }^{2}$ \\ Sekolah Tinggi Teologi Arastamar Bengkulu ${ }^{12}$ \\ *)Email Correspondance: overianushalawa90@gmail.com
}

\begin{abstract}
The 2019 coronavirus disease pandemic (covid-19) has damaged the order of human life as usual, including the world of education. In the world of education before the pandemic, parents completely handed over the responsibility of teaching to teachers in schools. But the covid-19 pandemic has turned it into the responsibility of teaching left to parents. The problem is, many parents are not ready to teach because they are not equipped with teacher education. As a result, parents are forced to teach with minimal knowledge so that the actions of parents often become victims of this unpreparedness. Since the covid-19 pandemic there have been some parents who abuse their children because they are difficult to teach. Moving on from this case, the researcher is interested in providing solutions to the struggles of parents when accompanying children to learn by using a qualitative approach by looking at the phenomena that occurred during the covid 19 pandemic. Based on the author's research, the right model for assisting parents in learning is teaching with repetitive, patient and creative.
\end{abstract}

Keywords: Parents, children, mentoring patterns.

Abstraksi: Pandemi corona virus disiase 2019 (covid-19) telah merusak tatanan kehidupan manusia seperti biasanya termasuk dunia pendidikan. Dunia pendidikan sebelum pandemi, orang tua menyerahkan sepenuhnya tanggung jawab mengajar kepada guru di sekolah. Tetapi pandemi covid 19 merubah hal itu menjadi tanggung jawab mengajar diserahkan kepada orang tua. Masalahnya, banyak orang tua yang belum siap mengajar karena tidak dibekali dengan pendidikan guru. Akibatnya, orang tua terpaksa mengajar dengan pengetahuan yang seadanya sehingga tindakan orang tua sering kali anak-anak menjadi korban dari ketidaksiapan tersebut. Sejak pandemi covid 19 ada beberapa orang tua yang menganiaya anaknya karena sulit untuk diajari. Beranjak dari kasus ini, peneliti tertarik untuk memberikan solusi terhadap pergumulan orang tua saat mendampingi anak belajar dengan menggunakan metode pendekatan kualitatif dengan melihat fenomena yang terjadi selama pandemi covid 19. Berdasarkan penelitian penulis, model pendampingan orang tua terhadap anak yang tepat dalam belajar adalah mengajar dengan berulang-ulang, sabar dan kreatif.

Kata Kunci: orang tua, anak dan pola pendampingan.

\section{PENDAHULUAN}

Pandemik coronavirus disease 2019 (covid-19) saat ini sedang melanda

dunia yang mengakibatkan banyak orang meninggal dunia dan mempengaruhi 
perekonomian serta berbagai kegiatan dunia termasuk Indonesia. Pandemik covid19 adalah penyakit menular yang disebabkan oleh sindrom pernapasan akut corona virus 2 (SARS-CoV-2). Jika dilihat dari berbagai berita maka Indonesia termasuk salah satu negara dengan jumlah angka penderita covid-19 paling meningkat, hal ini memicu adanya kebijakan pemerintah untuk menekan angka bertambahnya penderita covid-19, sehingga untuk memutuskan rantai penyebaran virus covid-19 ini maka pemerintah menetapkan himbauan untuk tetap menjaga jarak dengan orang lain, menjauhi kerumunan serta menghindari pertemuan yang melibatkan orang dalam jumlah banyak. Kebijakan pemerintah ini, berpengaruh pada dunia pendidikan sehingga pemerintah melalui Kementerian Pendidikan dan Kebudayaan (Kemdikbud) mengeluarkan instruksi mulai Maret 2020 untuk belajar dari rumah dengan menggunakan media daring/zoom.

Kebijakan pemerintah tersebut menimbulkan masalah baru bagi orang tua para murid yang akan mendampingi anaknya saat belajar daring dari rumah untuk belajar secara online sehingga dalam masalah tersebut banyak orang tua mengeluh dan menimbulkan amarah bagi orang tua yang mendampingi bahkan sampai melakukan tindakan kriminal kepada anak yang didampingi saat belajar. Tindakan kriminal yang dilakukan oleh orang tua murid saat belajar daring ditimbulkan oleh orang tua yang tidak sabar untuk mengajar sehingga menimbulkan emosi bagi orang tua. Menurut Komisi perlindungan anak, ada beberapa orang tua yang melakukan kekerasan terhadap anak dalam mendampingi anak belajar, ada yang melakukan kekerasan verbal dan kekerasan fisik seperti memukul saat belajar 
online. ${ }^{1}$ Dalam beberapa kasus yang terjadi, LH (inisial) seorang ibu rumah tangga yang tinggal di daerah kabupaten Lebak, Banten, tega menganiaya putrinya KS yang masih berusia 8 tahun hingga tewas karena sulit diajar ketika belajar dari rumah. ${ }^{2}$ Dalam beberapa laporan, ibu LH menganiaya putrinya karena kesal terhadap anaknya yang sulit diajari saat belajar online. Tidak hanya kasus LH di atas, namun ada beberapa orang tua yang melakukan tindakan penganiayaan dan kekerasan terhadap anaknya sendiri dengan berbagai alasan seperti belum siap mengahadapi keadaan saat ini, tidak sabar mengajar anak, anak yang diajar sulit untuk mengerti materi pelajaran yang diberikan oleh guru secara online. ${ }^{3}$ Selanjutnya ada orang tua yang tega memukul anaknya sendiri dengan menggunakan sapu lidi, karena anak tidak mengerti saat diajari oleh orang tua dalam mengerjakan tugas yang diberikan saat belajar online. Penyebab kekerasan orang tua terhadap anak dalam belajar salah satunya belum siap menghadapi sistem pembelajaran online, kesulitan ekonomi dan belum bisa menggunakan teknologi. ${ }^{4}$ Senada dengan pernyataan Tamara bahwa tidak semua orang tua siap menjalankan pekerjaan rumah dan sekaligus menjadi seorang guru. ${ }^{5}$ Inilah yang menyebabkan emosional orang tua terhadap anak.

Orang tua yang diperhadapkan dengan mengajar anak di rumah saat pembelajaran online sangat rentan dalam mengendalikan emosi sehingga berbuat

1 Tri Nathalia Palupi, "Tingkat stres ibu dalam mendampingi siswa-siswi sekolah dasar selama belajar di rumah pada masa pandemi covid-19," Jurnal Psikologi Pendidikan dan Pengembangan SDM 10, no. 1 (2021): 36-48.

2 Ivany Atina Arbi, "Kasus Orang Tua Aniaya Anak Saat Belajar Online Kembali Terekspos," Kompas.com, Desember 2020.

3 Retno Listyarti, "Anak Dibunuh Orang Tua karena Susah Belajar Online, KPAI Berduka," JPNN.Com, 15 September 2020. 20

4 Raihana Raihana, "Upaya Pengelolaan Emosi Ibu Pada Anak Selama Pembelajaran Dari Rumah (Dampak Pandemi Covid 19)," Generasi Emas: Jurnal Pendidikan Islam Anak Usia Dini 3, no. 2 (2020): 13242. 133

5 Josephine Tamara, "STRESS PADA IBU TERHADAP PEMBELAJARAN DARING SELAMA PANDEMI COVID-19," 2021. 11 
kasar terhadap anak yang didampingi dan diajari, ditambah dengan tekanan ekonomi dalam rumah tangga sehingga hal ini menimbulkan tekanan secara psikologi. Selain alasan di atas, orang tua juga mulai menyalahkan guru yang mengajar bahkan beberapa diantara orang tua tidak setuju dengan kebijakan pemerintah yang mengharuskan para murid untuk belajar dari rumah. Beberapa faktor yang memicu adanya keberatan orang tua tersebut yaitu ketidaksiapan dalam menyelesaiakan beberapa tugas yang diberikan oleh guru secara online, belajar online mengharuskan orang tua untuk belajar mengoperasikan aplikasi meeting zoom, sehingga orang tua yang belum terlalu tahu mengoperasikan mengalami kesulitan bahkan ada beberapa orang tua yang tidak bisa mencukupkan fasilitas dalam belajar seperti handphone atau kuota internet.

Beberapa keluhan di atas mempengaruhi pola pikir setiap orang tua sehingga mereka kesulitan dalam mendampingi anak mereka untuk belajar dari rumah. Alasan lain, selama ini orang tua merasa bahwa pendidikan adalah tanggung jawab guru yang mengajar di sekolah sehingga ada beberapa orang tua yang menyerahkan sepenuhnya tanggung jawab mendidik ke sekolah. Jika dilihat dari usia anak, secara khusus anak Sekolah Dasar (SD) memang sangat perlu pengawasan dan membutuhkan pendampingan orang tua dari rumah, dalam beberapa kasus ada orang tua yang mengatakan bahwa belajar di rumah sangat berbeda, biasanya anak itu lebih patuh dan taat terhadap guru dibanding dengan orang tuanya sendiri karena metode mengajar terbilang susah dan berulang-ulang. Selain itu juga, orang tua beranggapan bahwa belajar dengan didampingi oleh orang tua dari rumah jauh berbeda dengan belajar di sekolah karena guru di sekolah lebih memahami karakter dan kepribadian murid yang diajar, misalnya 
murid yang belum bisa membaca atau menulis, murid yang susah mengerti mata pelajaran dan sebagainya ${ }^{6}$.

Sejak pandemi Covid-19, semua proses belajar mengajar selama ini di sekolah dilakukan di rumah secara online. Para orang tua siswa harus mempersiapkan diri dengan menyediakan media yang mendukung seperti $H P$ android, laptop dan termasuk kuota internet. Selain itu juga, orang tua juga wajib mendampingi anak-anaknya selama belajar online. Hal ini yang membuat setiap orang tua belum siap menghadapinya. Beberapa orang tua mengaku bahwa pembelajaran dari rumah sangat sulit. Sebab, para orang tua memiliki alasan bahwa ketika anak belajar dari rumah maka bukan anak yang belajar tetapi orang tua yang belajar, karena materi yang disajikan secara online sulit untuk dipahami. Berdasarkan uraian di atas, kesuksesan seorang anak sangat bergantung dan berhubungan dengan peran orang tua dalam membimbing dan mendampingi anak selama belajar di rumah. Problem di atas menunjukkan bahwa orang tua anak membutuhkan hikmat dalam mendampingi anak-anaknya, sehingga perlu dirumuskan konsep teologis dalam mendampingi anak sebagai pengetahuan orang tua, untuk mencegah terjadinya tindakan-tindakan yang tidak baik terhadap anakanak yang sekolah secara online.

\section{METODE}

Metode yang dipakai dalam penelitian ini adalah pendekatan kualitatif. Dalam pendekatan kualitatif selalu berusaha untuk memperoleh kebenaran dari

6 Selfi Lailiyatul Iftitah dan Mardiyana Faridhatul Anawaty, "PERAN ORANG TUA DALAM MENDAMPINGI ANAK DI RUMAH SELAMA PANDEMI COVID-19," JCE (Journal of Childhood Education) 4, no. 2 (9 September 2020): 71, https://doi.org/10.30736/jce.v4i2.256. 
realitas yang sedang terjadi. ${ }^{7}$ Pendekatan kualitatif juga digunakan sebagai upaya menjelaskan bagaimana seorang individu melihat, menggambarkan hasil interaksi sosialnya menyangkut realitas yang terjadi. ${ }^{8}$ Realitas yang dimaksud dalam penelitian ini adalah menyangkut fenomena ketidaksiapan orang tua dalam mendampingi anak selama belajar online dari rumah. Selain pendekatan kualitatif, peneliti juga menggunakan studi pustaka untuk menemukan data-data mengenai cara orang tua mendampingi anak belajar di rumah. Menurut Sari dan Asmendri, Penelitian kepustakaan adalah penelitian yang dilakukan dengan mengumpulkan beberapa informasi dan data yang bersumber dari berbagia macam material baik dari perpustakaan atau sumber dari internet yang berkaitan dengan masalah yang ingin diselesaikan. ${ }^{9}$ Dalam hal ini peneliti berusaha menemukan data-data dari berbagai sumber baik literatur perpustakaan maupun literatur secara online untuk melakukan kajian teologis tentang pendampingan anak selama belajar online.

\section{HASIL}

Pandemi Covid-19 telah mengubah pola hidup manusia yang mengharuskan setiap orang untuk menyesuaikan diri dengan kondisi saat ini meskipun sulit untuk dijalani. Berbagai kasus di atas menunjukkan bahwa banyak orang tua para murid tidak siap untuk berhadapan dengan kondisi pandemi yang mengharuskan orang tua mendampingi anak belajar dari rumah. Kurangnya pemahaman orang tua tentang tanggung jawab dalam pendidikan anak merupakan

7 Tim Penyusun Kamus Pusat Pembinaan dan Pengembangan Bahasa, Kamus Besar Bahasa Indonesia, Kedua (Balai Perpustakaan, 1991).

8 Nanang Martono, Metode Penelitian Sosial Konsep-Konsep Kunci (Jakarta: PT RajaGrafindo Persada, 2015). 212

9 Milya Sari dan Asmendri, "Penelitian Kepustakaan (Lybrary Research) dalam Penelitian Pendidikan IPA," Natural Science, t.t. 
alasan utama, karena selama ini para orang tua memiliki pemahaman bahwa pendidikan anak merupakan tanggung jawab guru di sekolah sedangkan orang tua hanya sebatas memenuhi kebutuhan anak tersebut.

Perekenomian orang tua juga mempengaruhi terjadinya situasi seperti di atas, karena dalam belajar daring dari rumah pasti membutuhkan kuota internet dan minimal menggunakan handphone android. Sementara para orang tua tidak semua memiliki pendapatan atau perekonomian yang baik sehingga tuntutan tersebut membuat para orang tua menjadi labil dalam emosi dan anak yang menjadi korban. Faktor lain juga yang menimbulkan adanya kekerasan dan aniaya terhadap anak didorong oleh pendidikan orang tua yang rendah atau belum sekolah, sehingga ketika ada tugas dari guru secara online maka orang tua kebingungan dan mengeluh sehingga korbannya adalah anak.

Dari segi iman Kristen, peneliti melihat org tua melupakan janji kepada Tuhan saat anak dibaptis atau diserahkan kepada Tuhan bahwa mereka bertanggung jawab dalam mendidik anak untuk takut akan Tuhan dan bertanggung jawab juga dalam pendidikan umum sebelum anak mandiri/dewasa.

\section{PEMBAHASAN}

Setelah peneliti melihat beberapa kasus yang sedang terjadi saat ini tentang keluhan dan tindakan kriminal orang tua terhadap anak saat mendampingi belajar dari rumah, maka penulis memberi beberapa cara orang tua dalam mendampingi anak dalam belajar di masa pandemi covid 19.

\section{Mengajar Dengan Sabar}

Salah satu hal yang penting dalam mengajar adalah kesabaran, karena dengan memiliki sikap sabar maka seseorang mampu menemukan berbagai solusi 
dan menghadirkan dampak positif bagi anak didiknya. Yesus adalah satu-satunya guru agung yang memberikan teladan dalam mengajar. Yesus begitu sabar dalam menghadapi murid-murid bahkan setiap orang yang mengikut-Nya, yaitu Nikodemus (Yoh. 3: 1-21). Yohanes menceritakan bagaimana pertobatan Nikodemus yang disebut sebagai pemimpin agama Yahudi. Pertobatan Nikodemus berawal dari rasa penasaran terhadapan ajaran dan juga mujizatmujizat yang dilakukan oleh Tuhan Yesus. Nikodemus datang pada malam hari untuk bertanya kepada Tuhan Yesus tentang tanda-tanda yang Tuhan Yesus lakukan, meskipun Nikodemus adalah seorang pemimpin Yahudi yang terpandang, intelektual dan memiliki tradisi keagamaan yang radikal, namun tetap penasaran dengan apa yang dilakukan dan diajarkan oleh Tuhan Yesus. ${ }^{10}$ Hal itu terbukti Nikodemus datang pada malam hari menjumpai Tuhan Yesus (Yoh. 3: 2).

Kesabaran yang ditunjukkan oleh Tuhan Yesus terlihat ketika Nikodemus berulang-ulang memberi pertanyaan. Dalam teks ini, Nikodemus menyampaikan pertanyaan sebanyak 3 kali kepada Tuhan Yesus agar rasa penasaran tentang pelayanan dan pengajaran Tuhan Yesus dapat terjawab dan Tuhan Yesus dengan sabar menjawab setiap pertanyaan Nikodemus tanpa menghakimi ataupun mengusir Nikodemus. Sikap tersebut menunjukkan keteladan Tuhan Yesus tentang kesabaran, sehingga pada akhirnya pertemuan dengan Tuhan Yesus pada malam itu menolong Nikodemus untuk percaya pada Yesus Kristus. ${ }^{11}$

Kesabaran dalam bahasa Ibrani menggunakan kata "Erekh" yang artinya sikap atau karakter seseorang terhadap orang lain dengan tidak membalas

10 Hendrik Legi, "Implikasi Metode Mengajar Bagi Guru Pendidikan Agama Kristen," DIDASKO: Jurnal Teologi dan Pendidikan Kristen 1, no. 1 (22 April 2021): 20, https://doi.org/10.52879/didasko.v1i1.12.

11 Stimson B. Hutagalung, "NIKODEMUS: TEPATKAH SEBUTAN BAGINYA 'MURID RAHASIA'?," Jurnal Koinonia 1 (Desember 2019). 68 
kejahatan dengan kejahatan. Sedangkan dalam bahasa Yunani menggunakan kata "Makrothumia" artinya memiliki kesabaran dan tahan dalam penderitaan. ${ }^{12}$ Sehingga dapat dikatakan bahwa kesabaran merupakan suatu tindakan untuk menekan atau mengontrol emosi terhadap segala sesuatu.

Orang tua harus perlu belajar dari sikap Tuhan Yesus terhadap Nikodemus, yaitu: Pertama, mendampingi anak belajar di rumah bukanlah perkara yang mudah, karena membutuhkan komitmen dan kesabaran dari orang tua. Kedua, orang tua tidak mudah marah saat mendampingi anak. Ketiga, orang tua mampu mengendalikan diri ketika seorang anak sulit untuk diajar. Abineno menambahkan bahwa sebagai orang tua tidak boleh memancing amarah anak dan membuat terluka hati seorang anak, sehingga dapat menimbulkan luka batin dan akar pahit yang berdampak kepada pemberontakan. ${ }^{13}$ Penjelasan Abineno tersebut mempertegas bahwa dampak dari sikap orang tua yang yang tidak sabar dalam mendidik anaknya akan menjadikan anak tersebut menjadi seorang pemberontak. Untuk bisa mengajar yang baik orang tua harus terlebih dahulu hidup dalam ajaran dan nasihat Tuhan. ${ }^{14}$

Orang tua tidak boleh mendidik seorang anak hanya dengan memuaskan ambisi saja. Memuaskan ambisi yang dimaksud adalah seperti memaksa kehendak kepada anak untuk mendapatkan nilai yang tinggi dan wajib menjadi juara di kelas. Standar ini membuat orang tua memaksa anak untuk belajar keras dan kadang orang tua sampai memukul. Tindakan seperti ini bertentangan dengan

${ }_{12}$ Alfons Renaldo Tampenawas, Erna Ngala, and Maria Taliwuna, "Teladan Tuhan Yesus Menurut Injil Matius Dan Implementasinya Bagi Guru Kristen Masa Kini," EDULEAD: Journal of Christian Education and Leadership 1, no. 2 (December 10, 2020): 221, https://doi.org/10.47530/edulead.v1i2.44.

13 J.L.Ch Abineno, Tafsiran Alkitab Surat Efesus (Jakarta: BPK. Gunung Mulia, 2003). 224

14 Waharman Waharman, "PERAN ORANG TUA DALAM PERTUMBUHAN SPIRITUALITAS ANAK: SEBUAH STUDI EKSEGETIS EFESUS 6:1-4," Manna Rafflesia 4, no. 2 (3 Oktober 2018): 116-29, https://doi.org/10.38091/man_raf.v4i2.92.,117 
Alkitab. Alkitab mengajarkan orang tua harus sabar dalam mendidik anak. Kesabaran adalah salah satu bukti bahwa seseorang telah lahir baru. ${ }^{15}$ Kesabaran orang tua menjadi dasar agar anak tetap termotivasi dan antusias dalam belajar. ${ }^{16}$ Untuk menjadi sabar orang tua harus mengalami kelahiran baru, sehingga saat seorang anak memiliki tingkat akademik yang rendah maka yang dilakukan orang tua bukan memarahi tetapi memotivasi dan mendorong anak tersebut untuk semakin semangat belajar.

Orang tua yang bijak bukan hanya menerapkan didikan yang keras, tetapi juga mengarahkan serta membimbing anak tersebut menjadi pribadi yang baik dan bijaksana. Seorang ayah yang baik dimata Tuhan adalah seorang yang tidak ragu dan tidak segan menerapkan disiplin terhadap anaknya yang melakukan kesalahan. Terlebih lagi jika anak tersebut melakukan kesalahan berulang-ulang yang dapat merusak hidupnya. Namun, hal yang sangat diperhatikan oleh seorang ayah dalam mendisplinkan anak adalah disiplin yang membangun, tidak menghilangkan nyawa, atau mendisplinkan dengan tindakan kekerasan yang membuat anak mengalami luka batin. Hal tersebut perlu diperhatikan oleh orang tua ketika mendidik anak termasuk dalam mendampingi anak selama belajar dari rumah supaya anak mampu belajar tanpa tekanan dari orang tua dan anak akan semakin semangat untuk belajar.

Orang tua yang memiliki prinsip dalam mengajar dan mendidik anak akan menolong orang tua tersebut untuk mendidik dan mengajar anak dengan didikan dan nasihat di dalam Tuhan, meskipun sulit dan belum siap. Ayat $6 \mathrm{~b}$

\footnotetext{
${ }^{15}$ Manase Gulo, "Mengelola Perbedaan Menjadi Sebuah Kekayaan: Suatu Analisis Teks Kolose 3:12-17," Manna Rafflesia 7, no. 1 (31 Oktober 2020): 22-44, https://doi.org/10.38091/man_raf.v7i1.130. $19, " 2021$.

${ }_{16}$ Josephine Tamara, "Stress Pada Ibu Terhadap Pembelajaran Daring Selama Pandemi Covid-
} 
mengingatkan para orang tua agar menasihati anak dalam ajaran Tuhan. Kata

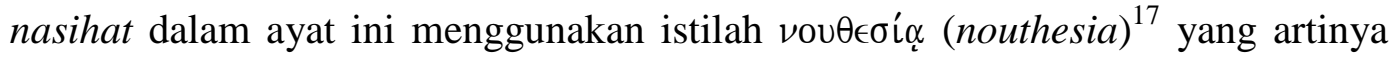
meletakkan sesuatu di dalam pikiran seseorang. Kata ini dipakai Paulus untuk mengingatkan para orang tua bahwa tugas mereka adalah membimbing dan mengarahkan anak mereka sesuai ajaran Tuhan, sehingga seharusnya orang tua memberi teladan takut kepada Tuhan dan lebih dulu menghidupi firman Tuhan supaya dapat mengarahkan anaknya ke dalam kebenaran dan jalan Tuhan sebab disiplin dan nasihat harus disertai dengan pengajaran yang dari Tuhan dan harus sesuai menurut ajaran kebenaran yang nyata dalam Kristus. Dalam Perjanjian Lama menjelaskan bahwa sebagai orang tua yang baik dan mengasihi anaknya harus menghajar pada waktunya (Ams. 13: 24), dan tongkat didikan akan menjadikan seorang anak menjadi bijak (Ams. 22: 15). Kedua ayat tersebut mengingatkan para orang tua untuk memiliki sikap tegas ketika anak berbuat kesalahan supaya anak tersebut menyadari dan tidak akan melakukan kesalahan yang sama, selain itu juga disiplin menjadikan seorang anak memiliki hidup yang teratur dan mandiri.

Situasi pandemik covid-19 di Indonesia membawa dampak positif bagi kehidupan keluarga, karena selama ini waktu untuk bertemu antara orang tua dan anak sangat sedikit karena orang tua sibuk kerja dan anak pun sibuk sekolah sehingga peran orang tua hanya bertanggung jawab dalam memenuhi kebutuhan materi anak. Namun pandemik covid-19 mengubah keadaan, sehingga orang tua menjadi lebih banyak waktu bersama dengan anak di rumah dan terjalin ikatan emosional lebih dari sebelumnya. Selain itu juga, anak dan orang tua memiliki

17 "nouqesi,a|" noun dative feminine singular yang berasal dari nouqesi,a (BMG Morphology, Word Analysis, s.v. "nouqesi,a" In Bible Works Version 8) 
waktu untuk berinteraksi. Sehingga secara tidak langsung belajar dari rumah secara online telah mengembalikan fungsi keluarga sebagai tempat utama terjadinya pendidikan bagi anak. Gunarsa menambahkan bahwa keluarga adalah dasar dari pendidikan, karena keluarga merupakan sumber utama dari pengetahuan serta kecerdasan intelektual. ${ }^{18}$

Peranan orang tua dalam mendampingi anak belajar dari rumah di masa pandemik covid-19 sangat dibutuhkan, karena belajar secara online dari rumah tidak sama dengan belajar secara tatap muka di sekolah. Anak sangat membutuhkan pengawasan dari orang tua baik dalam mengerjakan tugas-tugas dari guru secara online maupun dalam menyemangati anak tersebut untuk mengerjakan tugas. Menurut Gunarsa dalam perkembangan seorang anak, dibutuhkan lingkungan keluarga yang kondusif dan bebas dari gangguan, hal itu harus disediakan oleh orang tua karena itu merupakan salah satu syarat bagi kelancaran proses perkembangan anak. ${ }^{19}$ Hal ini yang perlu dihadirkan oleh para orang tua dalam membimbing dan mendidik anak-anaknya, sebagai orang tua perlu menerapkan disiplin yang bertujuan untuk terus mengarahkan anak untuk semangat belajar.

Dalam sebuah keluarga, orang tua memiliki tanggung jawab sebagai orang tua yang mencukupkan kebutuhan, sebagai pembimbing dan pendidik bagi anak. Perlu diketahui bahwa mayoritas orang tua belum mengetahui bagaimana konsep pendidikan keluarga itu, sehingga orang tua memiliki persepsi bahwa pendidikan adalah tugas seorang guru di sekolah. Seharusnya keluarga adalah pondasi pertama dalam pendidikan anak dan terbentuknya karakter anak. Paul David Tripp

${ }^{18}$ Singgih D. Gunarsa, Psikologi Untuk Keluarga (Jakarta: BPK. Gunung Mulia, 1976). 57

${ }^{19}$ Singgih D. Gunarsa dan Y. Singgih Gunarsa, Psikologi Praktis: Anak, Remaja dan Keluarga (Jakarta: BPK. Gunung Mulia, 1993). 24 
menjelaskan bahwa sebagai tempat untuk belajar, keluarga sangat berbeda dari ruang kelas. Ruang kelas bersifat hampa, terpisah dari dunia kehidupan luar. Di kelas kita berusaha untuk menciptakan kembali kehidupan sehingga kita dapat mempelajarinya. Tidak seperti ruang kelas, pengajaran dalam keluarga terjadi secara $\operatorname{spontan}^{20}$.

Orang tua seharusnya memberikan sebuah teladan yang dapat dicontoh oleh anak, orang tua juga harus menuntun anak dengan penuh kesabaran. untuk menuntun anak melalui ajaran, didikan, disiplin dan memberi nasihat pada saat anak melakukan kesalahan. Tuntunan dilakukan penuh kasih, kesabaran dan kelemahlembutan bukan kata-kata yang tidak membangun dan juga kata-kata yang tidak pantas serta kekerasan fisik tidak dilakukan di muka umum, sehingga anak menjadi paham apa yang patut dilakukan tanpa membuat anak menjadi murka, tawar hati, merasa terpojok, trauma dan kehilangan harga diri (Ef. 6: 4; Kolose 3: 21).

\section{Mengajar Dengan Berulang-Ulang}

Orang tua juga perlu belajar dari kehidupan bangsa Israel ketika Tuhan memberi perintah kepada mereka dalam menjaga hukum taurat dan mengajarkan kepada anak-anak mereka. Mengajar adalah suatu proses mengajar dan sekaligus memperingatkan. ${ }^{21}$ Dalam kitab Ulangan 6: 7 menjelaskan bahwa bangsa Israel diperintahkan oleh Tuhan untuk mengajar anak-anak mereka tentang shema dengan berulang-ulang. Hal tersebut merupakan prinsip yang diteladani dari cara mengajar orang tua bangsa Israel kepada anak-anaknya yaitu mengajar dengan berulang-ulang.

20 Paul David Tripp, Masa Penuh Kesempatan (Surabaya: Momentum, 2014), 40-41

${ }_{21}^{1}$ Manase Gulo, "BERTEKUN DALAM PEMBACAAN KITAB SUCI BERDASARKAN 1 TIMOTIUS 4:13," Manna Rafflesia 5, no. 1 (January 1, 2018): 50-68, https://doi.org/10.38091/man_raf.v5i1.98. 54 
Bangsa Israel adalah bangsa yang istimewa dihadapan Tuhan dan selalu berhasil dalam berbagai bidang, hal ini mereka alami karena mereka mendapatkan anugerah dari Tuhan sekaligus juga mereka menjalani proses yang Tuhan berikan. Salah satu proses yang harus dijalani oleh bangsa Israel adalah menaati hukum Tuhan atau yang disebut shema. Bagi umat Israel shema yang diterima tidak hanya berhenti pada pribadi, namun secara bersama diperintahkan oleh Tuhan untuk melakukan segala hukum taurat yang telah diterima dan juga menerapkannya kepada anak-anak. Rantesalu menjelaskan bahwa Allah memberikan perintah kepada bangsa Israel untuk mengajarkan kebenaran dan hukum Tuhan kepada anak-anak. Orang tua dari umat Israel perlu berupaya menggunakan beberapa cara seperti ritual, penghafalan hukum Tuhan dan juga beberapa instruksi-instruksi agar dapat diteruskan kepada generasi berikutnya. ${ }^{22}$ Perintah Allah untuk mengajarkan berulang-ulang kepada anak-anak merupakan salah satu cara orang Yahudi dalam menerapkan shema.

Orang-orang Yahudi adalah orang-orang yang taat kepada hukum Tuhan dan menerapkan setiap perintah Tuhan dalam kehidupan sehari-hari. Dalam ayat ini selain perintah dengarlah dan perhatikanlah, bangsa Israel juga diperintahkan untuk mengajarkan berulang-ulang. Kata berulang-ulang adalah kata kerja piel perfect yang berarti mempertajam. Para rabi menggunakan ayat ini sebagai shema ${ }^{23}$ yang perlu diulang setiap pagi dan sore, serta harus menjadi bagian hidup sehari-hari serta menjadi identitas pribadi.

22 Syani Bombongan Rantesalu, "Kompetensi Pedagogik Menurut Analisis Ulangan 6:7-9 Dengan Pendekatan Hermeneutik Schleiermacher," Jurnal Teologi dan Pendidikan Kristen Kontekstual (Desember 2018)154.

${ }^{23}$ Shema Yisrael dipandang sebagai doa yang paling penting di dalam agama Yahudi dan penyebutannya dua kali dalam sehari. shema adalah sebuah mitzvah (perintah rohani) dan inti utama dalam ayat tersebut adalah mencintai Tuhan dengan segenap hati, kekuatan serta hadiah yang muncul atas 
Tanggung jawab orang tua yaitu mengarahkan anak kepada hubungan yang dekat dan intim kepada Allah, karena selain tugas dari orang tua memenuhi kebutuhan anak, orang tua juga berperan memperhatikan kerohanian anak. Dalam ayat 7 Tuhan berfirman kepada orang Israel, supaya mengajarkan berulang-ulang dengan tujuan hukum dan perintah tetap tertanam dalam kehidupan anak-anak, sehingga anak-anak selalu ingat dan mampu menerapkan hukum dalam keseharian. Orang tua yang bertanggung jawab adalah orang tua yang memprioritaskan kerohanian karena karakter dan sikap anak ditentukan dari didikan orang tua dari rumah dengan terus memperkenalkan ajaran Tuhan dari usia dini. Cairns mengatakan bahwa bangsa Israel dihimbau untuk terus semangat dalam melakukan hukum Tuhan supaya hukum dan kehendak Tuhan dapat diteruskan dan dilakukan oleh generasi yang selanjutnya. ${ }^{24}$ Generasi yang dimaksud adalah anak-anak yang menjadi penerus dari bangsa Israel, sehingga diajarkan dari usia dini dengan berulang-ulang. Jika dilihat dari kata berulangulang, maka ajaran dan hukum itu harus dilakukan bukan hanya sekali saja tetapi berulang-ulang dimanapun dan kapanpun.

Orang tua membutuhkan proses yang panjang dalam mengajar anak, sampai anak mengerti dan mampu mandiri. Proses tersebut membutuhkan waktu, tenaga, pikiran dan komitmen orang tua dalam mengajar anak seperti dalam ayat 7 haruslah dengan berulang-ulang. Prioritas utama orang tua adalah memberikan pengajaran yang berkualitas. Hal itu sangatlah penting untuk dapat menyampaikan kebenaran Allah kepada generasi yang selanjutnya dalam menerapkan tradisi.

perbuatan itu. Istilah "Shema"' juga digunakan untuk merujuk kepada seluruh doa harian yang dimulai dengan Shema Yisrael dan terdiri dari Ulangan 6:4-9, 11:13-21, dan Bilangan 15:37-41. 135

24 I.J Cairns, Tafsiran Alkitab Kitab Ulangan Pasal 1-11 (Jakarta: BPK. Gunung Mulia, 2008). 134- 
Pengenalan akan Allah bagi bangsa Israel dijadikan sebagai gaya hidup. Kesadaran inilah yang menjadikan umat Israel berhasil mengajarkan Allah kepada anak-anaknya. Dalam Ulangan 6: 7-8 sangat jelas bagaimana cara bangsa Israel memberi pengajaran kepada anak-anak mereka tentang Allah dan hukum-hukumNya, agar diterapkan sebagai gaya hidup dan melekat dalam kehidupan seharihari.

Pola pengajaran orang tua Israel kepada anak tentang Allah sangat relevan untuk diterapkan oleh orang tua saat mendampingi anak-anak belajar online dimasa pandemik covid-19 yakni menerapkan pola mengajar secara berulangulang. Tujuannya supaya anak-anak mengerti dan tidak mudah melupakan apa yang telah diajarkan, karena orang tua mengajarkan secara berulang-ulang. Mengajar berulang-ulang berarti orang tua menyiapkan waktu yang banyak, mengajar berulang-ulang juga memberikan tenaga ekstra meskipun sudah lelah dalam bekerja namun karena anak menjadi prioritas maka orang tua perlu menyiapkan tenaga. Selain itu mengajar berulang-ulang juga perlu memiliki komitmen untuk mengajar sampai anak-anak mengerti.

\section{Mengajar dengan Kreatif}

Mengajar kreatif adalah salah satu pola yang efektif yang dilakukan orang tua terhadap anak dalam mendampingi anak belajar online dimasa pandemik covid-19. Kata kreatif (creative) berasal dari kata create yang berarti menciptakan sesuatu dan memiliki daya cipta. $^{25}$ Kreatif adalah kemampuan seseorang untuk menciptakan sesuatu yang baru, baik berupa gagasan maupun karya yang nyata serta memiliki ciri-ciri dalam berpikir kreatif maupun berpikir

25 Tim Penyusun Kamus Pusat Pembinaan dan Pengembangan Bahasa, Kamus Besar Bahasa Indonesia, Edisi Kedua. (Balai Perpustakaan, 1991) 530. 
secara afektif, baik dalam karya baru maupun kombinasi dengan hal-hal yang sudah ada dalam belajar.

Pengertian di atas mengingatkan para orang tua untuk mengajar anak dari rumah dengan kreatif dan menciptakan hal-hal baru dalam mendampingi anak, sehingga anak tidak menjadi bosan karena anak-anak pada umumnya cepat jenuh, stres dan cemas apalagi berhubungan dengan mata pelajaran yang tidak menarik. Menumbuhkan minat dan semangat belajar anak merupakan hal yang sulit bagi orang tua, selama pembelajaran dari rumah oleh orang tua selama mendampingi anak belajar di rumah di masa pandemik covid-19. Salah satu cara yang ampuh untuk mengantispasi yaitu orang tua perlu mengajar dengan kreatif, hal tersebut dapat dilakukan dengan jika anak sudah mulai bosan dengan mata pelajaran yang diberikan maka orang tua tidak boleh memaksakan anak untuk terus belajar. Orang tua perlu memiliki solusi dalam menangani perilaku seorang anak. Bisa saja orang tua memberi waktu kepada anak untuk bermain sejenak atau orang tua perlu memasak makanan yang disukai anak agar kembali semangat untuk belajar, tempat belajar juga bisa di dalam ruangan atau di luar ruangan, bisa juga belajar sambil mendengarkan musik sesuai dengan musik yang disenangi oleh anak, mengajar kreatif juga bisa dalam bentuk memberikan pujian atau bisa dalam bentuk teka-teki. Euis dkk. menambahkan bahwa sebagai solusi bagi orang tua dalam menumbuhkan semangat dan terhindar dari perasaan bosan maka orang tua harus melibatkan anak dalam menentukan kegiatan yang akan dilakukan. ${ }^{26}$

Yesus dalam mengajar selalu menggunakan perumpaan dengan memakai sarana yang ada disekitar-Nya. Tujuannya supaya pesan yang disampaikan saat

${ }^{26}$ Euis Kurniati, Dina Kusumanita Nur Alfaeni, dan Fitri Adriani, “Analisis Peran Orang Tua Dalam Mendampingi Anak di Masa Pandemi Covid-19," Jurnal Obsesi : Jurnal Pendidikan Anak Usia Dini, 2020. 246 
mengajar kepada pendengar dapat dimengerti. Inilah salah satu bentuk mengajar dengan kreatif, dalam mengajar Tuhan Yesus selalu menggunakan berbagai cara dan metode, seperti dari yang sederhana ke hal-hal yang rumit, dari hal-hal yang konkret ke hal-hal yang abstrak. ${ }^{27}$ metode seperti ini juga bisa diterapkan orang tua saat mendamping anak-anak belajar. Orang tua juga perlu bekerja sama dan menjalin komunikasi yang baik dengan guru untuk mewujudkan kelas yang kreatif dan inovatif, sebab tanpa menjalin komunikasi yang baik dengan guru dan memahami materi yang disampaikan oleh guru untuk diajarkan maka pembelajaran dari rumah tidak akan maksimal. Selain hal di atas, orang tua juga perlu belajar dari Youtube atau mengikuti seminar tentang cara mengajar anak dari rumah.

Pandemik Covid-19 menuntut peran orang tua untuk aktif secara maksimal dalam pembelajaran anak, misalnya dengan memberi semangat kepada anak untuk belajar secara online, memastikan anak belajar secara online dengan aman dan aktif berinteraksi dengan guru yang memberi materi. Selain hal di atas, orang tua juga harus terus memantau anak dalam mengakses internet. Karena tidak dapat dihindari bahwa perkembangan teknologi yang semakin canggih maka selain berdampak positif juga berdampak negatif terhadap perkembangan anak. Selama belajar secara online dari rumah, orang tua tidak dapat memungkiri bahwa anak cenderung cepat jenuh dan dapat mengakibatkan kehilangan semangat belajar. Untuk itu, orang tua harus kreatif dengan berusaha menciptakan suasana yang nyaman sehingga anak tidak cepat bosan misalnya orang tua perlu memberikan 
ruangan khusus kepada anak dapat fokus agar terhindar dari gangguan dan kebisingan orang lain.

Pendidikan bagi anak merupakan tanggung jawab orang tua dan bukan hanya tanggung jawab sekolah. Oleh karena itu, sebagai orang tua perlu memiliki peran dengan terus memberi motivasi kepada seorang anak dalam belajar, motivasi tersebut dapat berupa semangat untuk terus mengerjakan tugas-tugas dari sekolah dan juga apresiasi berupa pujian ketika seorang anak mendapat prestasi dari sekolah. Orang tua juga perlu memiliki sikap sabar dalam mendidik, membentuk, mengarahkan, membimbing, dan mendidik anak dengan berulangulang. ${ }^{28}$ Orang tua murid perlu belajar mengenal berbagai aplikasi yang digunakan oleh guru dalam proses belajar online. Betty dkk. Menuliskan bahwa pentingnya membangun komunikasi antara orang tua dan guru agar orang tua lebih memahami materi pembelajaran yang disampaikan oleh guru sehingga membantu orang tua dalam mendampingi anak selama belajar dari rumah dan sebaliknya, guru juga mampu memahami keinginan orang tua dalam mendampingi anak belajar dari rumah, yaitu dengan memberi materi yang dapat dimengerti dan dipahami, petunjuk untuk mengerjakan tugas harus jelas dan tugas-tugas yang diberikan tidak memberatkan anak. ${ }^{29}$ Cara ini membantu orang tua mendampingi anak belajar di rumah.

\section{KESIMPULAN}

${ }^{28}$ Anita Wardani dan Yulia Ayriza, “Analisis Kendala Orang Tua dalam Mendampingi Anak Belajar di Rumah Pada Masa Pandemi Covid-19," Jurnal Obsesi : Jurnal Pendidikan Anak Usia Dini 5, no. 1 (22 Agustus 2020): 772, https://doi.org/10.31004/obsesi.v5i1.705.

${ }^{29}$ Betty Kusumaningrum dkk., "Pendampingan Orang Tua Dalam Pembelajaran Daring di Sekolah Dasar: Evaluasi Pembelajaran Daring Selama Masa Pandemi Covid-19," Inventa: Jurnal Pendidikan Guru Sekolah Dasar, 2020. 147 
Melihat beberapa kasus yang terjadi di atas seperti menganiaya bahkan sampai menghilangkan nyawa anak yang didampingi dapat dipicu dengan ketidaksiapan orang tua dalam mendamping anak. Oleh sebab itu, dalam menghadapi ketidaksiapan tersebut maka orang tua harus menerima Tuhan Yesus secara pribadi dan memahami bahwa anak di bawah 12 tahun merupakan tanggung jawab orang tua dalam mendampingi anak belajar sama seperti orang tua Yesus pada usia 12 tahun. Selain menerima Tuhan Yesus secara pribadi, orang tua juga perlu memperbanyak mengikuti seminar, menonton Youtube untuk menambah pengetahuan bagaimana mendampingi anak belajar. Dengan demikian orang tua memiliki kreatifitas saat mengajar anak seperti belajar di tempat terbuka, belajar dari Youtube, sering mengikuti seminar tentang pendidikan anak, belajar sambil bermain serta menanamkan kebergantungan dengan Tuhan.

\section{DAFTAR PUSTAKA}

Abineno, J.L.Ch. Tafsiran Alkitab Surat Efesus. Jakarta: BPK. Gunung Mulia, 2003.

Arbi, Ivany Atina. "Kasus Orang Tua Aniaya Anak Saat Belajar Online Kembali Terekspos." Kompas.com. Desember 2020.

Cairns, I.J. Tafsiran Alkitab Kitab Ulangan Pasal 1-11. Jakarta: BPK. Gunung Mulia, 2008.

Gulo, Manase. "BERTEKUN DALAM PEMBACAAN KITAB SUCI BERDASARKAN 1 TIMOTIUS 4:13." Manna Rafflesia 5, no. 1 (1 Januari 1970): 50-68. https://doi.org/10.38091/man_raf.v5i1.98.

"Mengelola Perbedaan Menjadi Sebuah Kekayaan: Suatu Analisis Teks Kolose 3:12-17." Manna Rafflesia 7, no. 1 (31 Oktober 2020): 22-44. https://doi.org/10.38091/man_raf.v7i1.130.

Gunarsa, Singgih D. Psikologi Untuk Keluarga. Jakarta: BPK. Gunung Mulia, 1976. 
Gunarsa, Singgih D., dan Y. Singgih Gunarsa. Psikologi Praktis: Anak, Remaja dan Keluarga. Jakarta: BPK. Gunung Mulia, 1993.

Hutagalung, Stimson B. "NIKODEMUS: TEPATKAH SEBUTAN BAGINYA 'MURID RAHASIA'?” Jurnal Koinonia 1 (Desember 2019).

Iftitah, Selfi Lailiyatul, dan Mardiyana Faridhatul Anawaty. "PERAN ORANG TUA DALAM MENDAMPINGI ANAK DI RUMAH SELAMA PANDEMI COVID-19." JCE (Journal of Childhood Education) 4, no. 2 (9 September 2020): 71. https://doi.org/10.30736/jce.v4i2.256.

Kurniati, Euis, Dina Kusumanita Nur Alfaeni, dan Fitri Adriani. "Analisis Peran Orang Tua Dalam Mendampingi Anak di Masa Pandemi Covid-19." Jurnal Obsesi : Jurnal Pendidikan Anak Usia Dini, 2020.

Kusumaningrum, Betty, Kuncoro Krida Singgih, Tri Astuti Arigiyati, dan Trisniawati. "Pendampingan Orang Tua Dalam Pembelajaran Daring di Sekolah Dasar: Evaluasi Pembelajaran Daring Selama Masa Pandemi Covid-19." Inventa: Jurnal Pendidikan Guru Sekolah Dasar, 2020.

Legi, Hendrik. "Implikasi Metode Mengajar Bagi Guru Pendidikan Agama Kristen.” DIDASKO: Jurnal Teologi dan Pendidikan Kristen 1, no. 1 (22 April 2021): 12-24. https://doi.org/10.52879/didasko.v1i1.12.

Listyarti, Retno. "Anak Dibunuh Orang Tua karena Susah Belajar Online, KPAI Berduka.” JPNN.Com. 15 September 2020.

Martono, Nanang. Metode Penelitian Sosial Konsep-Konsep Kunci. Jakarta: PT RajaGrafindo Persada, 2015.

Palupi, Tri Nathalia. "Tingkat stres ibu dalam mendampingi siswa-siswi sekolah dasar selama belajar di rumah pada masa pandemi covid-19." Jurnal Psikologi Pendidikan dan Pengembangan SDM 10, no. 1 (2021): 36-48.

Pusat Pembinaan dan Pengembangan Bahasa, Tim Penyusun Kamus. Kamus Besar Bahasa Indonesia. Kedua. Balai Perpustakaan, 1991.

Raihana, Raihana. "UPAYA PENGELOLAAN EMOSI IBU PADA ANAK SELAMA PEMBELAJARAN DARI RUMAH (DAMPAK PANDEMI COVID 19)." Generasi Emas: Jurnal Pendidikan Islam Anak Usia Dini 3, no. 2 (2020): 132-42.

Rantesalu, Syani Bombongan. "Kompetensi Pedagogik Menurut Analisis Ulangan 6:7-9 dengan Pendekatan Hermeneutik Schleiermacher." Jurnal Teologi dan Pendidikan Kristen Kontekstual, Desember 2018.

Sari, Milya, dan Asmendri. "Penelitian Kepustakaan (Lybrary Research) dalam Penelitian Pendidikan IPA." Natural Science, t.t. 
Tamara, Josephine. "STRESS PADA IBU TERHADAP PEMBELAJARAN DARING SELAMA PANDEMI COVID-19,” 2021.

Tampenawas, Alfons Renaldo, Erna Ngala, dan Maria Taliwuna. "Teladan Tuhan Yesus Menurut Injil Matius dan Implementasinya Bagi Guru Kristen Masa Kini." EDULEAD: Journal of Christian Education and Leadership 1, no. 2 (10 Desember 2020): 214-31. https://doi.org/10.47530/edulead.v1i2.44.

Tuju, Rifky Serva. "Metode Mengajar Yesus menurut Injil Markus." Logon Zoes, Februari 2021.

Waharman, Waharman. "PERAN ORANG TUA DALAM PERTUMBUHAN SPIRITUALITAS ANAK: SEBUAH STUDI EKSEGETIS EFESUS 6:14." Manna Rafflesia 4, no. 2 (3 Oktober 2018): 116-29. https://doi.org/10.38091/man_raf.v4i2.92.

Wardani, Anita, dan Yulia Ayriza. "Analisis Kendala Orang Tua dalam Mendampingi Anak Belajar di Rumah Pada Masa Pandemi Covid-19." Jurnal Obsesi : Jurnal Pendidikan Anak Usia Dini 5, no. 1 (22 Agustus 2020): 772. https://doi.org/10.31004/obsesi.v5i1.705. 